\title{
The System of Proof on Extraordinary Crime in Case Criminal Which Based on the Intelligent Investigation Report (A Case Study)
}

\author{
Serfie D Bokko, (Corresponding author) \\ PhD Student, Department of Law, Sam ratulangi University, Manado, Sulawesi Utara, Indonesia \\ Wulanmas A. P. G. Fredrik, \\ Professor, Department of Law, Graduate Program, Sam Ratulangi University, Manado, Sulawesi Utara, \\ Indonesia \\ Ronald J Mawuntu, \\ Professor, Department of Law, Graduate Program, Sam Ratulangi University, Manado, Sulawesi Utara, \\ Indonesia \\ Devy K. G. Sondakh \\ Department of Law, Graduate Program, Sam Ratulangi University, Manado, Sulawesi Utara, Indonesia
}

\begin{abstract}
Terrorism is an extraordinary crime which is transnational activity that is way to combat terrorism not an easy operation, what more difficult and need highly activity and hardly unable to catch the terrorist, due process of it and challenging current criminal system procedure, whiles the burden of proof in terrorism is very complicated. Based on recent experience in Indonesia, due process of law for the act of terrorism does use the ordinary criminal system of procedure law, which does not adopt the intelligence investigation report as evidence based. In other word the law of criminal procedure act does not qualify yet or not clearly amend the intelligence report as clear convincing evidence. This study is tried to explore this gap on what other legal tool can be used to challenge this hole. What common practices is used to render this problem and what adjudge has been follow recently to this matter of law. The methodology in study this issues by collecting (i) all information related facts of intelligence operation analysis in formed part by part information followed by field cross-check examination, (ii) managing the crime of terrorism as extraordinary one and as the transnational of Crime against humanity based on the article 184 Criminal Procedure Act, with add some strong clues about terrorism activity as an preliminary evidence to continuing the depth investigation has been regulated according to article 26 Act No. 15 Year 2003 Regarding to The Prevention of Terrorism.(iii) By using intelligence investigation report as evidence the system of proof will bring some developing method for the law to foster the burden of proof system and may deter the crime of terrorism. As a conclusion this study may contribute some ways or other method of proof involving the extraordinary crime on terrorism which not been adopted by current law and system.
\end{abstract}

Keywords: burden of proof, evidence and terrorism, intelligence investigation

DOI: $10.7176 / \mathrm{JLPG} / 90-15$

Publication date:October $31^{\text {st }} 2019$

\section{A. Problem}

\section{INTRODUCTION}

Terrorism activity is being recognized as transnational activities, systemic and hardly to prevent or to proof in the court. There some legal limitations are existed in the system such as how is the act of the terrorism or acts of terror is an extra ordinary crime and for the law itself to be considered as special act of crime, which now is been governed on the Law of No. 5 Year of 2018 Regarding The Amendment of Act No. 15 Year 2003 Regarding The Stipulation of Government Act No. 1 Year 2002 Regarding The Prevention of Terrorism which later has been enacted to Act. However, the act of the terrorism now is still being be based on the law of current Criminal Procedure Act as been know KUHAP ${ }^{1}$ Moreover, this law, Criminal Procedure Act does not considered the intelligent investigation report as an evident or to be recognized as legal proof of the system of proof. Therefore, under the criminal procedure act $(\mathrm{CPA})^{2}$ is unable to unveil the master mind behind the scene, or the criminal master mind because of the limitation of this CPA itself. As the article 52 under the procedure act stated that the investigation in criminal process in finding the clues or in the court session, must consider the defendant

\footnotetext{
${ }^{1}$ Ari Wibowo, Hukum Pidana Terorisme (Yogyakarta Graha Ilmu, Cetakan Pertama 2012), h. 153

${ }^{2}$ KUHAP or Current Criminal Procedure Act, hereinafter as CPA(criminal procedure act)
} 
right and eligible to deliver his/her opinion in freedom to Judge or other investigators. ${ }^{1}$

The master mind of the terror may be anybody, usually has good background of education in related skill. They understand the law very well and accurately, grasp all the human rights issues and certainly they know every loop in the system of law. The Indonesian CPA is regulating the human right issues, compare to the previous one HIR which is not. The defendant human rights issues become week point for the law enforcement side, oppose to defendant side. This week-point as reason for the defendant human right issues has been prevail for long time. This loop hole may not make the root of the crime to be unveiling. The most quote on human right base issues is the presumption of law such as no quilt before court decision as been to adopt in CPA as well. ${ }^{2}$

Intelligence investigation report (IIR) ${ }^{3}$ is confidential and considerately accurate and final situation as the truth to be perceive as urgency and need to execute immediately. What act of execution could be precisely taken for? All acts which have been stated in criminal procedure act such as; cough, arrest, search and foreclosure. By doing this, the author believe that the law enforcer is not one step behind thus may prevent or cease the extra ordinary crime activity and may eliminate victim or other advance terror.

States that have been applied the IIR for legal evidence is Netherland. Seemingly become very effective in deterrence the terrorism compare to its neighbor countries like Germany, Denmark, France and Belgium. Handling extra ordinary crime may be preventing thru the existence of intelligent agent which is gaining the information thru other intelligence network and tool or media. Some evaluation might consider as to specific media as picture, drawn, recording, symbols, data analysis to produce IIR.

The article 26 and 27 of the Act No. 15 Year 2003 about the Stipulation of Government Regulation as an ACT which number No. 1 Year 2002 regarding The Prevention of Criminal Terrorism provide legal base for the prevention activity; Article 26 states that in order to gain preliminary evidence, the investigator may use every intelligence report, and in the Article 27 formulates that is the evidence rule does encompasses; a) evidence tool that is been stated on the criminal procedure act $b$ ) other evidence tool such as information that literally spoke out, sending, receiving or storing in the electronic devices using optical devices or element or same with that. Thus the IIR may be used for preventing, disturbing in order to diminish the event of terrorism that may incur wide damage of property or other victim.

Booming or suicide boom are seemingly escalated year by year and are doing by an ir-respectable person and antisocial personal diligently to create panic and fear in society. In the recent years the media have been reported, as the writer personal note that on 4 of July 2016 suicide boom in Arab Saudi, Arief Jeddah, in Medinah near the Masdjid Nabawi. 5 of July 2016 suicide bombing at Mapolresta Surakarta Solo Indonesia one day before Idul Fitri. 15 of July 2016 tragedy of truck chorusing crowed of people in France with gun shooting leave casualty 80 people dies. May of 22 year 2017 Manchaster bombing England at the concert of Ariana Grande. ${ }^{4}$ This is only a view example of terrorist activities has shown this world wide terror and fear. Target of this black harsh campaien is to spread out fear and chaos with no specific target but only innocent people. This strategy is more and more used by creating chaos and fear and make situation uncontrollable and put the mass in vulnerable situation and chaotic become easy target. The more chaos the more victim are getting. ${ }^{5}$

Again, terrorism is an extraordinary crime, crime against humanity are not slogan one. Based on some reports shown that the victim of terror are not limited to indiscriminative people but damaging or wiping out all economic resources and to be expected to create social and political turbulance. The terror may happen anytime anywhere because of its secrecy activity, well-plan and set up by skillful person until its active action. This is a serious imminent threat, and dangerous situation challenging every national security in the world. However, the prevention must be doing by an ad-hoc way and integrative manner.

Must be to recognition about difficulty in cope the master mind of terror under Indonesia current system. One of the stumble point is the camouflage activity which is commonly known using by such terrorist. The question in this legal chaotic is how to prove the activity camouflage? The law system which generally

83.

${ }^{1}$ Prija Djatmika, Selekta Kapita Penegakan Hukum, (Jakarta: Prestasi Pustaka, cet. Pertama 2006), h.

${ }^{2}$ M.Yahya Harahap, Pembahasan dan Penerapan KUHAP (Penyidikan dan Penuntutan) Jakarta (Sinar Grafika, Cet. Kesebelas) hlm.1

${ }^{3}$ IIR stand for Intelligence Investigation report, later quote as "IIR"

${ }^{4}$ For more event of terror might be seen Pada tanggal 23 mei 2017 ledakan Bom di salah satu Rumah Sakit di Philipina, Pada tanggal 24 Mei 2017 ledakan bom beruntun dalam hitungan menit di depan Terminal Kampung Melayu Jakarta Indonesia yang mengakibatkan satu anggota Polisi meninggal dan satu lainnya tangannya putus. Pada tanggal 4 juni 2017 terdapat terror bom di London Bridge Inggris, penembakan di Las Vegas 2017, pengeboman di Somalia 2017 dengan korban meninggal 358 0rang, Penembakan kerumunan orang di dalam Mesjid di Sinai Utara Mesir dengan korban meninggal dunia mencapai 305 jiwa dan luka-luka 128 orang, Pada tanggal 13 mei 2018 penyerangan tiga Gereja di Surabaya yang menewaskan 10 orang, pada tanggal 15 Maret 2019 penyerangan Mesjid di Christchuch New Zealand yang menewaskan 50 orang dan 20 lainnya luka-luka dan beberapa tempat lainnya.

${ }^{5}$ Sulistyo Hermawan. 2002. Bom Bali. Cetakan Pertama, Grafika Indah. 9 
recognized that is the legality principality as is been laid down by the law article 1 verse 1 of Criminal Law. " One particular act cannot be sentence unless there has been existed law(Nullun delictum nulla poena sine praevia lege ponali)" and one " particular person might not be in charge for the second time for the law has been settle by the court (nebis in idem) as been provided by the article 76 verse 1 the Criminal Law. ${ }^{2}$ One question left whether the article 1 verse 1 conflicts with article 76 verse 1 if one terrorist to be indictment accord to point 1 verse 1 and 2 to be charge according to the law of 15 Year 2003 Regarding The Prevention of Terrorism.

This is the limitation of our criminal procedure act vis a vis with burden of proof to terrorist activity. One of the advantage for the terrorist their have very close network and very secret. This unveiling method and network lead them to free access to gain power to control public. On the other side, law enforcement which is in this case, police officer or an intelligent agent against some limitation like time and other collectible facts. 1n 180 days, according to criminal procedure act, actually is not sufficient to gain strong evidence related to terrorism activities. Thus, if the law enforcement may not have the qualification evidence the person must be release at one. In fact, the law officer must submit those charge document to public prosecutor before it release. Using this method some time creates weakness for the public prosecutor because of lack of evidence in the court.

Against to this limitation or very crusial weakness of the law solution is given for at least one year. Law enforcement agent, wheater police officer, intelligent officer or public prosecutor to be granded extra time at least one year. The reason laid for this argument is in fact terrorism is diferent in nature. It is not conventional crime, it is an extraordinary crime, with closes operation and tends to victimize crowd and government facilities.

Based on this preposition the author would like to study about such system of proof in the criminal act on terrorism activity based on the IIR. According to the Act No. 15 Year 2003 IIR is considering as law evidence. Following to this reason, author needs to formulate some legal problem. First, What if those intelligence activity or information might be consider as evidence to build a case in criminal terrorisme matter. Second, What if the qualification of IIR to be qualify as evidence. Third, how is the Intelligence investigation report effect and contribution to the prevention of terrorism activity so far?

\section{B. Research Method \\ 1. Research Approach}

This research based on library research or normative juridical resources or primary law as statute or act. The research apply to other related law documents or resources such as legal bibliography, secondary law resources such as government policy or regulation, or rule ${ }^{3}$. Tertier data of law such academic journal, law journal on common law area and other Computer Assisted Legal Research such Lexis Nexis and WESTLAW, Black Dictionary recent edition.

\section{Data Collection Technic}

This is qualitative research on normative analysis approach. Technic to gain all information and primary, secondary or tertiere legal sources are mostly authoritative law document from law, statutory, Act or Government law and Court Decision, Law Journal, law books. Some law books or treaty may include.

\section{Data Collection}

Data or more specific are the information and mostly from books, Journal and other collected books or law and regulation. How to manage this information is by check and recheck until there is no hasitation about such clear and convincing data. By doing this actually the author apply snow balling technic.

\section{Data Analysis}

Data analysis is a method of analysis how this information is analyzing. Qualitative research on normative study as legal study open an opportunity to compare all information in the same category or different category. Evidence as research finding can be applied to research question. One must aware that most of legal research is searching normative and general principal of law which is must to apply to a specific rule of question. This is what is well known as deductive data analysis.

${ }^{1}$ Lihat Pasal 1 ayat (1) KUHP.

${ }^{2}$ Lihat Pasal 76 ayat (1) KUHP.

${ }^{3}$ Sri Mamudji et al. Metode Penelitian dan Penulisan Hukum, (Jakarta: Badan Penerbit Fakultas Hukum Universitas Indonesia, 2005), hal. 4-5. 


\section{RESEARCH FINDING AND DISCUSSION}

\section{A. Intelligent Investigation Report(IIR) ${ }^{1}$ as Evidence for Criminal Terrorism}

Again, terorism considers as transnational crime with specific nature and needs specific method of prove. The same thing is to cop and deal with this type of crime is different from the conventional crime. Practically in Indonesia, criminal terror are still adopting or more focusing on evidence at mainly. Article 184 verse (1) for example at Act No. 8 Year 1981 on Criminal Procedure Act mention it very hardly that legal evidence/validity of evidence are included only: 1 . Testimony of witnesses; 2 . Testimony of an Expert; 3 . Letters / documents; 4. Indication; 5. Defendant Answer/Testimony/Confession. About to this point of 5 difficult to gain because of the most of master mind of the terror, are in back of the scene and using many trick to hid his/her identity. Thus, the confession of the true actor/defendant is main obstacle in this problem since we can not access to his / her valid identity.

According to Act No 15 Year 2003, has been descript about the IIR which can be formulate that the IIR is a specific and sistimatic report and study with an analysis and evaluation report under particular operation using data factual such as, image, photo, recording, perforation, symbol-simbol and other devices that give special and uniqe meaning. The use of this IIR in the effort to open the existence of the crime may be used as preliminary evidence to continue the stage solid of investigation which later must under the Stipulation of the chairman/vice of the Court.

Following to this rule of evidence and also burden of proof, the criminal procedure act strongly stated that at least must have 2 (two) different evidence (of five) however the IIR may be recognize or strongly considered as an evidence of the case and from my personal view the IIR itself, in a nature, is not about a preliminary of indication but also is solid evidence. In this matter of argument, which may consider about the position of IIR that has been proof before by the chairman or vice charman of the court. Based on this ground, thus on the next coming bill of Amendment of Perpu No 1 Year 2002 on the prevention of criminal terrorism Act especially on article 26 may be suggest to this draft of law to stipulate that the IIR could be as legal evidence to used to adjuge the investigation process of terroris activity. More over, about the detention term which is on the act of Perpu provide only 6(six) month and which is stated on the criminal procedure act stated also in article 24 , $25,26,27,28$ and 29 cover all stages in inverstiation by police officer, public prosecutor, and on the Judge Circuit court, Appelate court until Supreme Court. Counting about the burden of proof, and profiling process of the subject or actor of the the terror the term 6 (six) month is must shortly.

Relativism in terrorism as a learning political states impacting us through the world of reality. We are combanting terror by all means, political campaigned, public policy, even war against it but in otherside this war at some glances may not true. As Peter Rosler-Garcia, political scientist and foreign economic, Humburg Germany stated there is no states in the world as consistently combating against the terror. ${ }^{2}$ Example to this, United States as the state war against the terror which its proganda Global War Against Terrorism, in fact on the other side support the terrorist "IRA" in North Irland or and Unita Movement in Angola. The same happen to Europan Uni support viaous of group of terrorist in Africa, Asia and Latin America include "ETA" in Spain. European city government in fact supported officially representing of an extremist in their region and accepting their activity thru silent. ${ }^{3}$ Further more, in this stage we are having difficulty in determint the true terrorism. Terror which is a term of terrorism veru ubsurd and subjective. Meaning, every person have their own state of mind about the measurement of fears, what is originally an event as terror the other not. ${ }^{12}$

Challenging the development of modern society with its modus operanti and crime like transnational terrorism, trafickking, narcoutic demanding other component of law to cope all of this development in crime world. The same question may be addressed to the legal system of our criminal procedure act. System burden of proof and the rule of evidence as been regulated in article 184 verse (1) stated that as a recording in persei never be a legal evidence. But in its ambiguity another statement shown as a recording apply to rule of indication. Strangely, this ambiguity is not finish, still there is another law, which the law of Information and Technology and electronica on article 5 statement (1) and (2) states that information of an electronical and documents/material or and electronical printed material considering "evidence" in persei or include in rule of evidence.

The specification about terrorism crime activity and any various of regulation in legal system are

\footnotetext{
${ }^{1}$ Intelligence Investigation Report hereinafter as IIR

2 Peter RÖsler-Garcia, "Terorisme, Anak Kanduk Ekstremisme", http://www.kompas.com/kompascetak/0210/15/opini/tero30.htm>, diakses 20 Februari 2009.

3 RÖsler-Garcia, Peter. "Terorisme, Anak Kanduk Ekstremisme", http://www.kompas.com/kompascetak/0210/15/opini/tero30.htm>, diakses 20 Februari 2009.

12 Paul Wilkinson, Terrorism and the Liberal State (London : The Macmillan Press Ltd., 1997), sebagaimana dikutip oleh F. Budi Hardiman dalam F. Budi Hardiman dkk., Terorisme, Definisi, Aksi dan Regulasi (Jakarta: Imparsial, 2005), hal 5.
} 
creating many language of manifestation and intepretaion. IIR as may conclude as a result of very attentive study and operational field have not been recognized as rule of evidence. Compare to other prevention program such as Commission the Eradication of Corruption that record the conversation of Artalyta considers against its individual interest, in other word shown the effectiveness of battle in corruption. ${ }^{1}$

In managing crime on terror, in Indonesia or other states seems tends to apply a conventional crime method which more behind the terror action. Specific crime must deal with specific method or rule. In this opportunity, the author is trying to explore about the IIR as my main purpose of this study. From this standpoint, the IIR focusing on proactive activity and doing nessecary action to prevent fallen of victim. Thus IIR is a method with aims no victim at all.

The IIR must take first place before the terror crime taken place, the intelligence operation must start to seek all fact and information, eye on eye, open their ears, identification object or seizuring the subject, monitoring, disturbing to hold the actor action in so may deminish the teror action. By do this, the production of IIR other people interest, especially their right to live are being protected. Based on this reason the author build this study to explore theoretically, how does the rule of evidence might be develop to cop the proble of burden of proof in terrorisme action.

Companion by the mothod of proof become a main support to discover the action of terror as been describe as IIR. Terrosrism as being recognize as a specific crime of terror in modern way needs special technic, special method and action in far. To re concerning about the past history of illegal recording as been recognized since hundred year ago or since the invention telecommunication in 1840 with telegrafi operation. One of the illegal recorded action when the telegrafi mechine send code by using morse code in 1867 .

Method of investigation with "illegal recorded" as an alternative method toward the development of crime in modern society. In this instance, the IIR become more strategic way or method in preventing or detection tool in combating terrorism.

The development of the information and technology in Indonesia does bring the sindicate and terrorism group in and it demands the Indonesian law enforcement to be adapted in a unigue way to develop their skill and knowledge. Including of this, a need of develop a new rule of evidence as been mentioned before if the IIR are the component of a rule of evidence as we cconsult to 5 of rule of evidence in article 184 from the criminal procedure act.

Compare to another draft law (bill) which is the bill of new criminal procedure act year 2008, about the rule of evidence there some development. Before on the recent applied law, the criminal procedure act stated only five rule of evidence such as:

1. Item/Clues

2. Leters/document

3. Testimony of the witnesses

4. Expert Testimony,

5. Defendant Testimony

Now in a new draft of the Bill, the new law which under preparation to parliament is becoming six of rule of evidence to be include electronic devices.

Standard of burden of proof or rule of evidence as is in criminal procedure act and in the Criminal Act are becoming late up-dated compare to the development of crime. IIR must be legally to accept in the context of its systematic of evidence which using surveillance method, operation action, field analysis of fact, data transmitting, recording, picture, image, or profiling all of this make the IIR most comprehensive method and evidence and it's a evidences in one package. All of this is about the authorization of a specific particular act which is not allow in general term for the sake of special needs in a special condition such as in the existence of terrorisme. The effort to combat terrors in the future must be seen some individual interest might be vistimised for the sake of nation and state security.

Freedom of communication and on the accepting of information stated by the article $28 \mathrm{~F}, 28 \mathrm{G}$ statement 1 of the 1945 Constitution must be seen as a relative statement means it may be deviate in the case of specific legal reasoning (lex specialis derogat legi generali).

In this case, the IIR with its comprehensive nature can be applied adequately as of the rule of evidence. The existence of present law which is conflicting each other brings some confusing. For instance the way of recording or method of recording particular subject must object to the law that oblige the enforment to be based on legal interest of law, and the action to recording must under permission of related body.

The rule of evidence especially about the indication element as is meant by the article 188 verse 2 in the Act of No. 8 The CPA specially for the criminal special act for terrorism is been recognized by the law that evidence such (a) other evidence like information which literally spoken out, by sending, by accepting, or in

\footnotetext{
${ }^{1}$ Munir Fuady, Teori Hukum Pembuktian (Perdata dan Pidana), Citra Aditya Bhakti, Jakarta, 2006, hal.181.
} 
store of in electronic way using optical means or same with in; and (b) document which means every recording, data information that is to be seen, read, or listening by or it can be visualize or without any help or any means, or other that can be paperised including drawn, voices, map, pictures, draft or blue printing, number or perforation that has a meaning. The extention of the rule of evidence is a need because of the terrorisme nature as an extra-ordinary crime which is where the evidence lead to an actor is most difficult.

\section{B. The Usage of IIR in Crime of Terrorism}

In daily exercise, when dealing with terrorism case law enforcer using conventional way, which is apply the procedural general criminal procedure where usually using the article 184 Criminal procedure act on burden of proof and rule of evidence, like Letter. According to the acticle 184 :

(1) "Letter" composed of Akta (Official Letter) or other kind of Letter. Akta is a script which merely to be made to show about one event.

(2) Witness. Testimony after examination of proof is a way examination of proof is the importance in the case examination process before the judge. Thus, one testimony must confirm about evenevent which he/her personally was seen or experiencing not only one conclusion from those experience. Only the Judge that may taken the conclusion. ${ }^{1}$ In the terrorism activity where social and religious mask used by an actor evidence of letter to be perceive not enough and strong. Another is in the testimony itself in this case, is not the perfect one and bind the judge, but must be leave to the judge to accept those testimony or not. Meaning the judges are free to consider one testimony according to his/her personal perception. One witness that has close family relationship with defendant in case may be repudiate by another party meanwhile such witness may ask to release her/him to give the testimony. Further more the law stipulates that one testimony does not adequate. Means one judge can not his decision on one testimony. Thus, this testimony must be side by side with another kind of evidence. ${ }^{2}$

(3) Asumsing is a conclusion that is taken from an event in clear and factual. From this clear and factual event the conclusion is taken and another event already happen. In cross examination stage, there two kind asumtion that may adopt, which the assumption by law (ducth: watterlijk vermoeden) and assumption by Judge (rechtelijk vermoeden). ${ }^{3}$ Asumptions are difficult to apply in terror case .

(4) Confession. Actually confession is not the evidence rule, because of if one party confess about something then other party is free not need to confess something. Thus, it can say that this party or that party has proved something. Because the examination of proof the examination before the judge has not in burden of proof examination process. ${ }^{4}$

(5) By law there two kinds of sworn which decisive sworn (decissoire eed) and compliment sworn (supletoir eed). The first one is a sworn which under order by one party which aim to to end the battle. ${ }^{5}$ If for instance the other party take the sworn with text draft by other party and then this party is won. In return, if this party repudiates to take sworn then he loses. Party has been order to take a sworn has the right to ask the opponent to take a sworn.

(6) Indication is an evidence according to the law. There are another kind of evidence which is not considered by the law such photo, film, video-or $\mathrm{CD} /$ tape recorded, micro film and microchip. According Supreme Court Letter. ${ }^{6}$ Nomor 37/TU/88/102/Pid Januari 14, Year 1988, mikrofilm atau mikrofische may consider as an evidence with some exception the originality or authentification of the item and it could trace back its registration and protocol. This rule apply to civil and criminal case. ${ }^{7}$

Court of terrorist session is very specific in nature and it also need aiding tool to uncover it and the IIR which inside full of high tech information acted like in two side of a knife. One side may save the human life another side may destroy the life itself.

It is so happen with the technology itself, law and the crime are two coins vis a vis. Law is response the

${ }^{1}$ Ibid, $180-181$.

${ }^{2}$ Ibid

${ }^{3}$ Ibid, hal. 181-182.

${ }^{4}$ Ibid.

${ }^{5}$ Ibid, hal. 183-185.

${ }^{6}$ Hari Sasangka, Hukum Pembuktian dalam Perkara Perdata Untuk Mahasiswa dan Praktisi, CV. Mandar Maju, Bandung, 2005, hal. 41.

${ }^{7}$ Dikdik M. Arief Mansur dan Elisatris Gultom, Cyber Law Aspek Hukum Teknologi Informal, PT. Refika Aditama, Bandung, 2005, hal. 100. 
rapid growing of modern behavior in other side law may have to face the crime itself that come from its modern behavior. Thus, crime has come into the era which what so called "Cybercrime." Cybercrima can be describe simply an act of crime using computer technology or computer or computer network (local area network) or external network to access, without permission certainly, and tortiously with or without damaging or change on the computer facility it access in. ${ }^{1}$

The actor of the terror identity difficult to find and also difficult to uncovered thtough confesion merely. The actors are mostly has under strong indoctrinate and perceive to suicide in return for their "belief". Thus, confession before the Judge (gerechtelijke bekentenis) consider onesided confession either on writing or orally on the bench. Which is to agrred or not agreed about the relation that submit by other party in court whether the examination are in or stop in". ${ }^{2}$

As we discuss about the limitation of proving the terrorism activity in court using the conventional rule of evidence and method of proof as been stated above. The extentive of rule of evidence such as IIR must be exercise at once. The character of the intelegence process are cepat (velox) dan repat (Exactus) are considering the essence of an intelegence in nature, both are two side of a coin, intelligence means capacity to learn without difficulty beside the character of an individual in a new era can satisfy its elf its environment. ${ }^{3}$

Herbert L. Packer devides criminal justice system in two model: crime control model and due process model. ${ }^{4}$ To support this argument Packer stated that in his book The limits of the Criminal sanction, "I call this two models the Due process Model and the Crime Control model". 5.

Indonesia uses the due process model. "Due Process Model" is a enforcement that tends to prevention side, using presumption of innocent, formality, adjudicative and legal quilty efficiency. In the investigation the constitution provide privilege to police officer to call, investigation, detention, seisuring, or to take legally all item/property that needs for further investigation specially related to a crime. In exercising this authority, the enforcement subject to the right of due process of law where where every person under investigation has their right to be perform (due process of law). ${ }^{6}$ In this situation, in a context of terrorism the author submit this suggestion that in the case of terrorism the enforment process would choose the crime control model before the fallen happen in the next future.

The application of law on the terrorism war if it applied the crime control model where involves law professional with fully understood the pcriminal process because of its tendency in repressive movement, presumption of innocent and the guilty factual efficiency. This is become more efficience in dealing with terrorism because process of terrorism activity challenging two issues human right and the burden of proof.

Some facts are finding by law enforcement very often the enforcement process stuck into the wall side one case must adjourne because of lega; procedure with tend to emphysis the due process model. Thus in the combat of terrorism is more efficiently using crime control model. This tactic is more preserve the public, save their interest and it can decrease crime and punish the quilty one.

Thus in this opportunity, I might suggest that the IIR in the examination process of terrorism even is a difficult one but for the sake of preserving people and the protection life one may suggest the usage of crime control model where the officer is in the involving those who are skillfull and full of knowledge.

\section{The Impact of The Change System on Method of Proving Towards The prevention terrorism Crime}

The IIR become more important as a foundation for building up an effective way to prove any terror activity. Many task force are already in with some tries or simulation to positively convince the terror operation. The terrorist usually seek for a weakness point and exploit this point as a target which not under protection or less security. The operation of terrorist is exercise as clandestine / under groung operation which well organized and with special training. Acton to secure usually for the a team who will do the terror, with cell cell group action before destroy the target.

Implication of the IIR related to terrorism become more influence to prevent the acceleration and the terroris maneuver. The terror action beside creating fear in public the terror also impact the whole system of life ideology, politics, economy and culture even security itself. So, the changing of proving method will bring down the $\mathrm{i}$ of terror. As for example Osama Bin Laden as the main enemy of the USA. He with his aids AL Qaeda to be perceive anti capitalism. Meanwhile for certain group of people Osama and its organization to perceiving as a

1 Dikdik M. Arief Mansur dan Elisatris Gultom, Cyber Law: Aspek Hukum Teknologi Informasi, PT. Refika Aditama, Bandung, 2005, hal. 8.

2 R.M. Sudikno Mertokusumo, Op. Cit., hal, 107.

${ }^{3}$ Opcit Hendropriyono. hal. 27

${ }^{4}$ Romli Atmasasmita. 2010. Sistem Peradilan Pidana Kontemporer. Cetakan Kedua. Jakarta: Kencana Prenada Media Group. hal. 11.

${ }^{5}$ Herbert L. Packer. The Limits of the Criminal Sunction. California: Stanford University Press, California. Hlm.

\footnotetext{
${ }^{6}$ Harahap M.Y. 1985. Pembahasan dan permasalahan KUHAP. Jakarta: Sinar Grafika. Hlm. 95.
} 
hero against the US arrogant and its neo capitalism. However this is the war between lunatic fanatic and religious radicalis and neo capitalism and capitalism.

The aims of every religion basically blessing for people and bring a message of peace for people of the world. The terrorist this chance to another side where a religion to be ideologed with different meaning. Where religion treata as a vehicle for power. Political situation after WTC New York, at September 112001 make change the world map drastically lead by US. America accommodated a new foreign policy as pre-emtive movement, consilidates foreign corporation among countries in the world to combat terrorism and network.

Impact of WTC Booming creates such as "travel traumatic" on people in the world uses airplain. Many airline corporation experience damage in their financial and budget operation. The war against terror lead by America has crossed out the domestic border.Genuinly terrorism is a crossed out the domestic border too. Example to this how the America government decides to combat Afganistan and Iraq. This is a leasson learning which if we put the IIR at first we would not have such casualty of terror with a massive damage of life and property.

\section{A. Conclusion}

\section{CONCLUSION AND RECOMMENDATION}

Based on research and this study therefore some point might be provide as is;

1. On this analysis dealing with war in terror or terrorism we better use the IIR as an important alternative vehicle or as an evidence using in the examination of proof. Quick respons and the fast pf terrorism activities needs to consolidate all resources to stop the eccelaration of terror. IIR become major vehicle to combat terrorism

2. By using the IIR as an evidence or include in the rule of evidence may eliminate victim and damage in all level and deter the terrorism.

3. In this world the actor of terrorism are in every side of the world therefore the way to deter in by using IIR as a evidence to identify, monitor and hunting down the actor..

Terrorism is a extra ordinary crime therefore to dealt with it must in with in the extra ordinary method in this case the IIR is suggested.

\section{B. Recommendation}

1. To bring the government awarness that war without terrorism is futile without the IIR method.

2. Terrorism in this study shown as a war against humanity, massive, systemic and well organized. In the context of investigation may be recommended that the term of detention to be prolonged until a year period to explore the terrorist networkingand all of its plan.

3. To call the awareness of the legislator and all the law enforcement sector to consolidate this matter in deterrence of terrorism attack. Based on this research, the recommendation goes to the follow research and its agenda in this area of study to preform it with different approach. Those study is consider as a contribution for a nation.

Aditya Bhakti, Jakarta, 2006.

\section{REFERENCES}

Andi Hamzah, Pengantar Hukum Acara Pidana di Indonesia, Jakarta: Ghalia Indonesia, 1985.

Black, Donald., Sociological Justice, Oxford University Press, New York, 1986.

Bryan A. Graner, Black's Law Dictionary Eighth Edition (St. Paul: West Thomson, 2004).

Budiarjo, Miriam., Dasar-Dasar Ilmu Politik, PT. Gramedia, Jakarta, 1987.

Effendi, H.A. Masyhur., Hak Asasi Manusia Dalam Hukum Nasional Dan Internasional, Ghalia Indonesia, Jakarta, 1994.

Firdaus, Kamal., Pelaksanaan Undang-undang Hukum Acara Pidana dan Hak Asasi manusia Dalam Perspektif Kepengacaraan, Makalah Diskusi Panel di FakultasHukum UII Yogyakarta, tanggal 10 Desember 1994

Grolier Academic Encyclopedia, Grolier International, 1983.

Hendropriyono A.M. Filsafat Intelijen Negara Republik Indonesia. Buku Kompas. 2013.

Lembaga pendidikan dan latihan Polri, Fungsi Teknis Intel, Polri, Jakarta, 1992

Manoppo, H.A., Sepintas Tinjauan Mengenai Adanya Hak-hak Asasi Manusia di dalam Hukum Acara Pidana Negara Indonesia, Hukum dan Keadilan No. 1 Tahun VI, Mei-Juni 1978. 
Marwan Effendy, Korupsi dan Strategi Nasional, Jakarta Selatan, 2013.

Munir Fuady, Teori Hukum Pembuktian (Perdata dan Pidana), Citra.

Poernomo, Bambang., Pokok-pokok Tata Acara Peradilan Pidana Indonesia, Liberty, Yogyakarta, 1986.

Prakoso., Kedudukan Justisiabel Di dalam KUHAP, Ghalia Indonesia, Jakarta, 1986.

Prints, Hukum Acara Pidana dalam Praktik Jakarta: Penerbit Djambatan, 1998.

Rahardjo, Hukum, Masyarakat Dan Pembangunan, Alumni, Bandung, 1976.

Reksodiputro, Hak Asasi Manusia Dalam Sistem Peradilan Pidana, Lembaga Kriminologi Universitas Indonesia, Jakarta, 1994.

R. Soernarto Soerodibroto, KUHP dan Kuhap, PT. Raja Grafindo, Jakarta,

Rosler-Garcia, "Terorisme, Anak Kandung Ekstremisme", http://www. kompas. com/kompascetak/0210/15/opini/tero3 0. htm>, diakses 20 Februari 2009.

Setiawan, M. Arif., Pelaksanaan KUHAP Dalam Perspektif Hak Asasi Manusia, Makalah Diskusi Panel Di Fakultas Hukum UII Yogyakarta, Tanggal 10 Desember 1994.

Soekanto, Soerjono., Faktor-faktor Yang Mempengaruhi Penegakan Hukum, Rajawali Pers, Jakarta, 1983.

Sulistyo Hermawan. Bom Bali. Grafika Indah. 2002.

Sunaryati Hartono, Peranan dan Kedudukan Azas-Azas Hukum Dalam Kerangka Hukum Nasional, FH. UNPAR, Bandung, 1987.

Wahid, Abdul dan Muhammad Labib. Kejahatan Mayantara (Cybercrime). Bandung: PT. Rafika Aditama, 2005.

Wikipedia Online Encyclopedia, "Definition of Intellegence," http://en.wikipedia.org/wiki/Intellegence>, diakses 23 Desember 2009.

----------, Kriminologi Dan Sistem Peradilan Pidana, Lembaga Kriminologi Universitas Indonesia, Jakarta, 1994.

----------, Masalah Penegakan Hukum, Sinar Baru, Bandung, 1978.

----------, Simposium Penegakan Hukum, Bina Cipta, Jakarta, 1982.

Undang - Undang :

Undang - Undang Nomor 8 tahun 1981 Tentang Hukum Acara Pidana.

Undang-Undang Nomor 15 Tahun 2003 tentang Pemberantasan Tindak Pidana Terorisme.

Internet :

Dikutip dari "Intelligence Analysis", http://faculty.ncwc.edu/toconnor/427/427 lect04. htm, diakses pada 29 desember 2009.

Dikutip dari "Counterintelligence", http://faculty.ncwc.edu/toconnor/427/427lect09.htm

Wikipedia Online Encyclopedia, "Definition of Intellegence," http://en. wikipedia.org/wiki/Intellegence>, diakses 23 Desember 2009. 